IRSH 54 (2009), Supplement, pp. I-I7 doi:I0. Io I 7/So0208590099902 I 6 (C) 2009 Internationaal Instituut voor Sociale Geschiedenis

\title{
Ottoman and Republican Turkish Labour History: An Introduction
}

\author{
Touraj Atabaki \\ Internationaal Institunt voor Sociale Geschiedenis \\ E-mail: tat@iisg.nl \\ GAVIN D. BROCKETT \\ Department of History, Wilfrid Laurier University \\ E-mail: gbrockett@wlu.ca
}

In European parlance prior to the twentieth century, “Turkey" and "Turk" were common epithets used to refer respectively to the Ottoman Empire and generally to the Muslim population of the Middle East. Strictly speaking, however, no state by the name of Turkey existed until the formal proclamation of the Republic of Turkey in October 1923, while those who self-identified as Turks were limited largely to the cultural elite inspired by ethnic nationalist ideas emanating from Europe in the latter part of the nineteenth century. Subsequent to the dissolution of the Ottoman Empire following its defeat in World War I, the Republic of Turkey was one of many new nation-states to be established in the Middle East, and its ruling elite set about forging a Turkish nation inclusive of all those who found themselves living within the boundaries of the new country.

Turkey, therefore, is an entity very distinct from the vast empire ruled by the Ottoman dynasty, which spread from its origins in north-western Anatolia to incorporate not only the remainder of the Anatolian peninsula and much of the Caucasus, but also North Africa, Arabia and the Fertile Crescent, the Crimea, the Balkans, and much of south-eastern Europe. Centred on Istanbul (Constantinople), following its capture in I453, the Ottoman Empire was a multi-ethnic and multi-religious polity that played an integral part in the economy and politics of both Europe and Asia throughout its six centuries of existence. By contrast, the Republic of Turkey, centred on the capital of Ankara, has been content to function as a self-contained nation-state with strong ties to both Europe and the Middle East. Significantly, the population of Turkey today is overwhelmingly Muslim, although it is far more ethnically diverse than the state might like to acknowledge. 
The historiographies of the Ottoman Empire and Turkey are distinct, although they are intimately connected if only because modernist historians, both in Turkey and beyond, contrived a historical narrative after I 923 that was predicated upon a representation of the Ottoman heritage as disreputable and shameful. According to this narrative, prior to the foundation of the Republic of Turkey the Ottoman Empire was the "sick man of Europe", whose Sultan Abdülhamid reigned for thirty-three years (1876-1909) "as a terrified animal, fighting back blindly and ferociously against forces that he could not understand". Then "he was thrown into a panic by Turkish reformers and Westernizers, who became increasingly terroristic in the face of his opposition". ' Whereas the Turkish nationstate was to be progressive, modern, and "secular", ${ }^{2}$ the Ottoman Empire had been backwards, despotic, and mired in religious superstition. The modernist perspective, therefore, emphasized the necessity of a complete break with the immediate past and a republican Turkey thoroughly independent of the Ottoman Empire. ${ }^{3}$

The question remains, of course, whether this narrative is valid, whether prior to 1923 the Ottoman Empire was indeed suffering from corruption, ignorance, and stagnation. In recent years scholars have begun to challenge the modernist paradigm and there is now a multiplicity of narratives. With reference to Abdülhamid II alone, Erik-Jan Zürcher has noted that:

[Hamidian] rule has been the subject of great controversy. Nineteenth-century Europeans came to see him, especially towards the end of his rule, as a bloodthirsty and reactionary tyrant. [....]. The historians of the Turkish Republic, which itself was the legacy of the Young Turks who forced Abdülhamit from power in 1908-9, likewise see him as a reactionary, who for a generation halted the regeneration of the empire. Modern historians of Turkey since the 1960 s have drawn a different picture, emphasizing the way in which his reign marked a continuation, or even the culmination, of the Tanzimat and the benefits it brought to the empire and its population. ${ }^{4}$

As the case of Abdülhamid suggests, Ottoman history is being reclaimed and rehabilitated by scholars both in Turkey and beyond, and there exists an increasingly rich literature exploring diverse aspects of

I. Robert Roswell Palmer and Joel Colton, A History of the Modern World: Since I8IS (London, I992), p. 657.

2. The very meaning of this term as applied to Turkey is contested and frequently misunderstood. There is a growing literature on the meaning of Turkish secularism, recognizing the continued importance of Islam to Turkish society and culture. Whatever else it may mean, "secular" does not denote the absence of religious practices and beliefs in Turkish society at any point in time.

3. Touraj Atabaki, Beyond Essentialism: Who Writes Whose Past in the Middle East and Central Asia? (Amsterdam, 2003), pp. I3-I4.

4. Erik Jan Zürcher, Turkey, A Modern History (3rd edn, London, 2004), pp. 76-77. 
Ottoman society, culture, economy, and politics. The same, however, is less true of republican Turkish history, which only more recently has begun to break with the extremely resilient nationalist-modernist narrative: only now is the focus shifting away from the person and ideas of Turkey's founding president, Mustafa Kemal Atatürk (I88I-I938), towards a broader exploration of Turkey's past. This includes the emergence of a new social history of Turkey, one that explores the experiences of the people who actually lived through and underwrote the end of the empire and the establishment of a new nation-state. ${ }^{5}$

The present Supplement to the International Review of Social History continues in this vein, examining the social history of both the Ottoman as well as the republican period by studying its labour history. The focus is specifically upon the history of labour in that part of the Ottoman Empire - Anatolia and eastern Thrace - that would later be incorporated into the new Republic of Turkey, and the history of labour in Turkey itself. It represents the work of a growing number of young scholars who, in recent years, have responded to Donald Quataert's efforts to draw attention to the importance of labour history, and who have taken seriously his admonition to engage in further research along these lines if only to "break down the artificial barriers that nation-state historiographies are helping to maintain". ${ }^{6}$ Quataert made this case very clearly in his Introduction to the edited volume, Workers and the Working Class in the Ottoman Empire and the Turkish Republic, I839-1950, published in I995 in conjunction with the International Institute of Social History.

In this Supplement, we bring together Ottoman and republican Turkish historiographies, demonstrating that in many ways the social histories of the Ottoman Empire and Turkey intersect in the history of labour. Historians may debate the relationship of Turkey to the Ottoman Empire, but an examination of labour history offers scholars the opportunity to identify those aspects of the historical experience that are distinct to the two polities, as well as those that transcended the end of empire and the emergence of the Turkish nation-state.

Labour history has long been the preserve of scholars in "the West", typically viewed from the perspective of the north Atlantic region, but in recent years this has begun to change. A previous Supplement to the International Review of Social History examined aspects of South Asian

5. For early literature that contributed to this shift see Sibel Bozdoğan and Reşat Kasaba (eds), Rethinking Modernity and National Identity in Turkey (Seattle, WA, 1997), and Gavin D. Brockett, "Collective Action and the Turkish Revolution: Towards a Framework for the Social History of the Atatürk Era (1923-1938)", Middle Eastern Studies, 34:4 (1998), pp. 44-66.

6. Donald Quataert, "Introduction”, in Donald Quataert and Erik Jan Zürcher (eds), Workers and the Working Class in the Ottoman Empire and the Turkish Republic, I839-1950 (London, 1995), p. I7. 
labour history, ${ }^{7}$ and this signalled recognition that not only is the history of labour in non-Western countries worthy of study, but that scholars in those countries themselves have an important contribution to make to the larger field. What recently has been referred to as the "global labour history" ${ }^{\prime}$ is itself a step beyond what were essentially the Eurocentric "old" and "new" labour histories that scholars have engaged in over the past one-and-a-half centuries. Up to this point, however, the new global labour history has focused primarily on Asia, Africa, and Latin America.

The relative absence so far of the Middle East in this scholarly discourse has been noteworthy: it figures rarely in the literature related to global labour history. That said, however, research on Middle East labour history has been ongoing for some time now, but more often than not it has only drawn the attention of those working in the field of Middle East studies. ${ }^{9}$ Among seminal works are those dealing with both Palestine and Egypt. ${ }^{\text {I0 }}$ On a number of occasions, the work of diverse scholars has been published in collected volumes, ${ }^{\text {II }}$ while articles addressing specific topics have appeared in a variety of journals, including the International Journal of Middle East Studies ${ }^{\mathrm{I2}}$ and Middle Eastern Studies. ${ }^{\mathrm{I}}$ It is only recently

7. See the Supplement to the International Review of Social History, 5 I (2006): Rana P. Behal and Marcel van der Linden (eds), Coolies, Capital, and Colonialism: Studies in Indian Labour History.

8. Marcel van der Linden, "Labour History: The Old, The New and the Global", African Studies, 66:2-3 (2007), pp. 169-180.

9. A valuable recent summary of the state of the field is Joel Beinin, Workers and Peasants in the Modern Middle East (Cambridge, 200I).

ı. Zachary Lockman, Comrades and Enemies: Arab and Jewish Workers in Palestine, 1906-1948 (Berkeley, CA, I996); Joel Beinin and Zachary Lockman, Workers on the Nile: Nationalism, Communism, Islam and the Egyptian Working Class, I882-1954 (Princeton, NJ, 1987).

I I. Çağlar Keyder and Faruk Tabak (eds), Landholding and Commercial Agriculture in the Middle East (Albany, NY, 199I); Donald Quataert (ed.), Workers, Peasants and Economic Change in the Ottoman Empire, 1730-1914 (Istanbul, I993); Zachary Lockman (ed.), Workers and Working Classes in the Middle East: Struggles, Histories, Historiographies (Albany, NY, 1994); Ellis Jay Goldberg (ed.), The Social History of Labor in the Middle East (Boulder, CO, 1996).

I2. Recent articles include Joel Beinin, "Labor, Capital, and the State in Nasserist Egypt, 1952-196I", International Journal of Middle East Studies, 2 I (1989), pp. 71-90; Sohrab Behdad and Farhad Nomani, "Workers, Peasants, and Peddlers: A Study of Labor Stratification in the Post-Revolutionary Iran”, International Journal of Middle East Studies, 34 (2002), pp. 667-690; Kamran Asdar Ali, "The Strength of the Street Meets the Strength of the State: The 1972 Labor Struggle in Karachi”, International Journal of Middle East Studies, 37 (2005), pp. 83-107; Martin Latreille, "Honor, the Gender Division of Labor, and the Status of Women in Rural Tunisia - A Social Organizational Reading”, International Journal of Middle East Studies, $4 \circ$ (2008), pp. 599-62 I.

I3. For instance, articles on labour in the Ottoman Empire and Turkey include Theo Nichols and Erol Kahveci, "The Condition of Mine Labour in Turkey: Injuries to Miners in Zonguldak, 1942-90", Middle Eastern Studies, 31:2 (1995), pp. 197-228. Christopher Clay, "Labour 
that the occasional article on labour in the Middle East has begun to appear in general journals of labour history. Both the International Review of Social History and International Labor and Working-Class History have promoted the study of non-Western labour history, and on occasion this has included the Middle East. ${ }^{\mathrm{I}}$

Among historians of the Middle East, Quataert has been largely responsible for establishing Ottoman labour history as a viable field of research. To be sure, various scholars have published studies that examine aspects of working life in the premodern Ottoman Empire, ${ }^{15}$ but it is Quataert's numerous monographs and articles that have focused attention on the experiences of workers at the end of empire, and on late Ottoman social history as a whole. ${ }^{16} \mathrm{~A}$ critical step in this direction was the publication

Migration and Economic Conditions in Nineteenth-Century Anatolia”, Middle Eastern Studies, 34:4 (1998), pp. I-32; Burhanettin Duran and Engin Yıldırım, "Islamism, Trade Unionism and Civil Society: The Case of Hak-İș Labour Confederation in Turkey", Middle Eastern Studies, 41:2 (2005), pp. 227-247; N. Sugur and S. Sugur, "Gender and Work in Turkey: Case Study on Women Workers in the Textile Industry in Bursa", Middle Eastern Studies, 4I:2 (2005), pp. 269-279.

I4. Yair Seltenreich, "Jewish or Arab Hired Workers? Inner Tensions in a Jewish Settlement in Pre-state Israel”, International Review of Social History, 49 (2004), pp. $225-247$. See also the articles devoted to the special theme, "Twentieth Century Iran: History from Below" in part 3, volume 48 of the International Review of Social History (December 2003), edited by Touraj Atabaki and Marcel van der Linden; Behrooz Moazami, "The Striking Cabbies of Cairo and other Stories: Crafts and Guilds in Egypt, I863-1914" (book review), in International Labor and Working-Class History, 69 (2006), pp. 2 I3-2 I 5; Asef Bayat, "Workless Revolutionaries: The Unemployed Movement in Revolutionary Iran", International Review of Social History, 42 (1997), pp. I 59-I 85; David De Vries, "Productive Clerks: White-Collar Productivism and StateBuilding in Palestine's Jewish Community, I920-1950", International Review of Social History, 42 (1997), pp. 187-2 18; Onur Yildirim, "Ottoman Guilds as a Setting for Ethno-Religious Conflict: The Case of the Silk-Thread Spinners' Guild in Istanbul”, International Review of Social History, 47 (2002), pp. 407-419.

I 5. See for instance Minna Rozen, "The Corvée of Operating the Mines in Siderokapisı and its Effects on the Jewish Community of Thessaloniki in the I6th Century", Balkan Studies, 34 (1993), pp. 29-47; Onur Ylldirim, "Transformation of the Craft Guilds in Istanbul during the Seventeenth and Eighteenth Centuries (I650-1826)", Revue des Etudes Sud-Est Européennes, 37-38 (1999-2000), pp. 91-109; idem, "Ottoman Guilds as a Setting for Ethno-Religious Conflict", pp. 407-419; Șevket Pamuk, "Urban Real Wages around the Eastern Mediterranean in Comparative Perspective, I 100-2000", Research in Economic History, 23 (2005), pp. 209-228; Suraiya Faroqhi, "Water, Work and Money-Grabbing: Mobilizing Funds and Rural Labour in the Bursa Region around I600", Archivum Ottomanicum, 23 (2005-2006), pp. I43-154. The work of Suraiya Faroqhi, whose publications are too numerous to list here, has been particularly important in opening up the social history of the Ottoman Empire. For further discussion on this see Donald Quataert, "Labor History and the Ottoman Empire, c. 1700-1922", International Labor and Working-Class History, 60 (200I), pp. 93-109.

16. Among these see Donald Quataert, Social Disintegration and Popular Resistance in the Ottoman Empire, I881-1908: Reactions to European Economic Penetration (New York, 1983); idem, Ottoman Manufacturing in the Age of the Industrial Revolution (Cambridge, 1993); Manufacturing in the Ottoman Empire and Turkey, I500-1950 (Albany, NY, I994); idem, 
of a series of articles devoted to Ottoman labour history and introduced by Donald Quataert in International Labor and Working-Class History in $2001 .{ }^{17}$

As Quataert acknowledged in 1995, historians of Ottoman and Turkish labour have struggled to break with a number of established traditions in the larger field of labour history. Here it is helpful to recognize these so as to understand the contribution that the essays in the present Supplement make to the new global labour history. First and foremost, this volume marks a determined effort to eschew the long-standing dominance of the modernization paradigm. Labour history has long been dominated by a structural-functionalist theory of modernity that, until recently, was also a foundational element of the historiography of the Ottoman Empire and Turkey. This approach assumes that the onset of modernity inevitably led to urbanization, industrialization, and secularization, as well as to the emergence of a proletariat. For all that it challenges in terms of the traditional historical narrative of Western history, its application to nonWestern histories nonetheless, rather ironically, uncritically subscribes to a Eurocentric historicism. ${ }^{18}$ In the case of the Ottoman Empire and Turkey, the prevailing assumption was that modernization was inspired solely by Ottoman and/or Turkish contact with "the West", and that a Westernized elite then imposed "reform" and "change" on a backwards people in desperate need of enlightenment. ${ }^{19}$

The influence of the modernization paradigm on labour history is such that all too often emphasis has been on the evolution of workers into organized groups capable of engaging in strikes and acting out a conscious political identity as the natural progression of history. A second tradition among labour historians, therefore, has been to focus exclusively on the emergence of working-class consciousness to the exclusion of all else.

\footnotetext{
"Ottoman Women, Households and Textile Manufacturing, I800-1914", in Nikki Keddie and Beth Baron (eds), Women in Middle Eastern History (New Haven, CT, I991), pp. I6I-176; and Halil İnalcik and Donald Quataert (eds), An Economic and Social History of the Ottoman Empire, I300-I9I4 (Cambridge, I994).

17. The following articles appeared in issue 60 (2001) of International Labor and WorkingClass History: Donald Quataert, "Labor History and the Ottoman Empire, c. 1700-1922"; idem and Yüksel Duman, "A Coal Miner's Life during the Late Ottoman Empire"; Fariba ZarinebafShahr, "The Role of Women in the Urban Economy of Istanbul, I700-1850"; Cengiz Kirl, "A Profile of the Labor Force in Early Nineteenth-Century Istanbul"; and John Chalcraft, "The Coal Heavers of Port Sa'id: State-Making and Worker Protest, I869-19i4".

18. Max Weber, Die protestantische Ethik und der Geist des Kapitalismus (Munich, 2006), or, more recently, David Harrison, The Sociology of Modernization and Development (London, I988).

19. Prominent studies influenced by this perspective include Niyazi Berkes, The Development of Secularism in Turkey (London, 1999), and Bernard Lewis, The Emergence of Modern Turkey (2nd edn, Oxford, i968).
} 
In the case of Turkey, there is evidence of a long-standing preoccupation with this question as well as an assumption, on the part of some, that it was the state that generated this identity among workers rather than that they themselves were responsible agents capable of developing their own autonomous identity.

There is a legitimate question as to how unskilled labourers gained a common identity, in the process becoming "workers" with a political purpose - or, to use the Turkish terms, how amele (unskilled individual toilers) became iş̧̧ (the labouring collective masses). ${ }^{2 \circ}$ From the point of view of the state, such a collective identity constituted a threat to efforts to inculcate popular loyalty to the new nation-state. This tension was particularly evident at the Izmir Economic Conference of 1923, where Mustafa Kemal sought to coopt workers for the formation of the nationstate and to deny the existence of a common working-class consciousness. Although Feroz Ahmad asserts that this consciousness existed apart from the state, he nonetheless accepts that Mustafa Kemal largely succeeded in this effort by monopolizing ideology in the one-party state. ${ }^{2 \mathrm{I}}$ True to a degree, such a conclusion nevertheless reifies the long-standing and rather uncritical acceptance of the power of the Kemalist state that, in turn, justifies the failure of scholars to examine the subject any further - even though there is evidence of considerable dissent below the surface. ${ }^{22}$ Yet, the role of the state continues to loom large in the historiography of Turkey, and in a recent study Ahmet Makal examines the consolidation of class identity as a result of state legislation. In his study there is no reference to workers as autonomous agents, their other identities, or their changing ways of life. ${ }^{23}$

If scholars have proven themselves susceptible to accepting the role of the state in defining and limiting a working-class consciousness in Turkey, then there has also been a tendency to focus primarily on the role of labour unions and on activism in the form of public strikes as a demonstration of that consciousness. ${ }^{24}$ This third characteristic follows very

20. See Feroz Ahmad, “The Development of Working-Class Consciousness in Turkey”, in Lockman, Workers and Working Classes in the Middle East, pp. 133-164.

21. Ibid.

22. For hints of leftist and labour efforts to counter state dominance see Mete Tunçay, Türkiyede Sol Akrmlar Ii (1925-I936) (Istanbul, I992); Özgür Gökmen, "The State of Labour in Turkey, 1919-1938”, Mitteilungsblatt des Instituts für soziale Bewegungen, 33 (2004), pp. I23-I 36; Cem Emrence, 99 Günlük Mubalefet: Serbest Cumburiyet Firkası (Istanbul, 2006). 23. Ahmet Makal, Ameleden isçiye: Erken Cumburiyet Dönemi Emek Taribi çalışmaları (Istanbul, 2007).

24. See the following essays in Quataert and Zürcher, Workers and the Working Class in the Ottoman Empire and the Turkish Republic: Yavuz Selim Karakışla, "The Emergence of the Ottoman Industrial Working Class, I839-1923"; Erdal Yavuz, "The State of the Industrial Workforce, I923-40"; and Mehmet Șehmus Güzel, "Capital and Labor during World War II". 
much the agenda of what scholars refer to as the old labour history, ${ }^{25}$ with its emphasis upon the institutional aspects of labour and on labour militancy in its relations with the state. The early history of labour in Turkey is no exception, for here labour activism has been studied largely to the exclusion of what might be called the "life of the working class". ${ }^{26}$

It is important, therefore, to move beyond this paradigm and to adopt aspects of the new labour history. As an alternative to the institutional preoccupations of the old school, according to this new approach labour history must expand to include issues such as gender and sexuality, ethnicity and/or race, age, the structure of households, as well as informal social and political relationships. ${ }^{27}$ This is almost certainly a reaction to the need for theoretical integration that can explain not only the dynamics of class relations but also highlight historical discrepancies within class identities themselves. Significantly, proponents of the new labour history have been scholars of both Western and Asian labour history: ${ }^{28}$ in the case of the latter, Ranajit Das Gupta has questioned the authority of the old labour history by refuting Marxist economic determinism in favour of a culturalist approach to narrating the place of labour in history. ${ }^{29}$

Ideology, of course, has played a prominent role in informing labour history, and a final observation concerns the tendency among historians to equate the history of labour with leftist ideology and movements. Here, Turkey is a case in point, for in the I960s and I970s a new generation of Turkish intellectuals themselves were heavily influenced by leftist ideas and extremely active in Turkey's tumultuous political debate of these years. ${ }^{30}$ Thus, there has been the tendency to link the chronology of labour history with a chronology of leftist political parties. ${ }^{3 \mathrm{I}}$ No doubt

A more recent study is by Peride Kaleağası Blind, "A New Actor in Turkish Democratization: Labor Unions”, Turkish Studies, 8 (2007), pp. 289-3 I I.

25. For a detailed discussion of the old and the new labour history see Thomas A. Krueger, "American Labor Historiography, Old and New: A Review Essay", Journal of Social History, 4 (197I), pp. 277-28 5. See also David Brody, "The Old Labor History and the New: In Search of an American Working Class", Labor History, 20 (I979), pp. I I I-I 26.

26. See for example Türkiye Isci Sinifi ve Mücadeleleri Taribi (Ankara, 1976).

27. For calls to further scholarship along these lines, see Lex Heerma van Voss and Marcel van der Linden (eds), Class and Other Identities: Gender, Religion and Ethnicity in the Writing of European Labour History (New York, 2002); Marcel van der Linden, Workers of the World: Essay toward a Global Labor History (Leiden, 2008).

28. Ira Katznelson and Aristide R. Zolberg (eds), Working-Class Formation: NineteenthCentury Patterns in Western Europe and the United States (Princeton, NJ, 1986), p. I4.

29. Ranajit Das Gupta, "Indian Working Class: Some Recent Historiographical Issues", Economic and Political Weekly, 3 I (24 February 1996).

30. For an overview of these years, see Zürcher, Turkey, A Modern History, pp. 24I-277.

3. See D. Shishmanov, Türkiye'de Işci ve Sosyalist Hareketi (Sofia, I965). For a more recent study, see Sencer Ayata and Ayșe-Güneș Ayata, “The Center-Left Parties in Turkey”, Turkish Studies, 8 (2007), pp. 2 I I-232. 
certain aspects of Turkish labour history are tied to political debate and the emergence of various leftist parties, but this cannot be allowed to obscure those aspects of Turkish labour that were not ideologically or politically charged. This is but one of the challenges facing the new generations of historians who must examine the history of labour within the larger context of Turkish history.

The inclusion of the Ottoman Empire and Turkey within the purview of the new global labour history provides valuable impetus to recent efforts by historians to overcome the pervasive influence of the nationalist narrative that has dominated the historiography of Turkey. In the i950s, while the hold of this narrative over the history of the Ottoman Empire began to dissolve, at the same time it became enshrined as the only acceptable way to view republican Turkish history - in both English- and Turkish-language scholarship. ${ }^{32}$ Consequently, the historiography of the late Ottoman Empire is better developed precisely because scholars especially those who are themselves Turks - found it more acceptable to examine aspects of the Ottoman past than to call into question the official narrative of Turkish history. One contribution these scholars made was to our understanding of the incorporation of the Ottoman Empire into the world economic system and hence the generation of conditions within which organized labour emerged in the late nineteenth century. ${ }^{33}$

Among the industrial enterprises that became identified with organized labour at precisely that time was coal mining - particularly mining carried out in the Zonguldak-Ereğli coalfields on the north-west Black Sea coast. If there is one area of Ottoman/Turkish labour history that is well developed then it is this, for as early as 1974 Delwin Roy published an article on the Zonguldak strike of $1965 .{ }^{34}$ Since that time the Zonguldak-Ereğli coalfields have become the focus of considerable scholarly attention, in part because of the serendipitous discovery of a wealth of documents that allowed Donald Quataert to write his landmark Miners and the State in the Ottoman Empire: The Zonguldak Coalfield, I822-1920. In this work Quataert draws on his extensive familiarity with labour historiography as a whole to address many of the shortcomings of labour history referred to earlier in this Introduction. ${ }^{35}$

32. See Gavin D. Brockett, 'How Happy to Call Oneself a Turk': Provincial Newspapers and the Negotiation of a Muslim Identity in Modern Turkey (forthcoming).

33. See for example Reșat Kasaba, The Ottoman Empire and the World Economy: The Nineteenth Century (Albany, NY, 1988); Çağlar Keyder, State and Class in Turkey: A Study in Capitalist Development (London, 1987). See too Salih Özbaran, Tarih Ve Ögretimi (Istanbul, 1992).

34. Delwin Roy, "The Zonguldak Strike: A Case Study of Industrial Conflict in a Developing Society”, Middle Eastern Studies, I0:2 (1974), pp. I42-185. Two years later, Roy published a second article, "Labour and Trade Unionism in Turkey: The Ereğli Coalminers", Middle Eastern Studies, I 2:3 (1976), pp. I $25-172$.

35. Donald Quataert, Miners and the State in the Ottoman Empire: The Zonguldak Coalfield, I822-I920 (New York, 2006). 
Interestingly, it is a publication that appeared in Zonguldak in 1934 that illustrates clearly just how important the study of labour history can be to the overall study of Turkish history in light of the prevailing nationalisthistorical narrative. On the eleventh anniversary of the Republic of Turkey (29 October 1934) the Zonguldak newspaper issued a special sixteen-page edition that trumpeted the benefits of life in republican Turkey as compared with that in the Ottoman Empire. ${ }^{36}$ The cover page presented a picture of Mustafa Kemal superimposed on images from Zonguldak's coal and shipping industries, while subsequent articles traced the national and local impact of Kemalist efforts to transform village life, education, the economy, public works, as well as the place of youth and women in society. ${ }^{37}$

The layout of this edition was particularly suggestive, for on the lefthand side was a description of one of these subjects in terms of "The former Turkey/Ottoman Empire" with the subheading "we received it in this form", while on the right-hand page the same subject was examined in terms of "New Turkey" with the subheading "we transformed it in this way". Throughout, the emphasis was upon the corrupt nature of Ottoman politics and society as well as the crushing weight of European imperial designs as these affected all aspects of life, and the dramatic transformation inspired by Mustafa Kemal resulting in national freedom and growth. Turks were not permitted the luxury of romanticizing their Ottoman past but rather were told unequivocally that it was worthy of shame and rejection; Turkish identity, therefore, had to be rooted in the present and the future, wrought by Mustafa Kemal, and the source of immeasurable pride.

This was the perspective that infused the nationalist narrative that, in turn, has defined Turkish historiography for so long. It was consistently echoed in numerous government publications from the period, ${ }^{38}$ and these in turn served as the foundation for both an ideologically driven history that continues to be published in Turkey today, ${ }^{39}$ as well as for important studies that came to define the English-language historiography of Turkey for subsequent decades. ${ }^{40}$ This historiographical tradition depends heavily on a

\footnotetext{
36. Zonguldak, 29 Ortagüz (Ilkteşrin) I934.

37. The subjects covered were: "Eski Türkiye Osmanlı Imperatorluğu; Yeni Türkiye"; "Eski Koy, Yeni Koy"; "Ümmet Maarifi, Millet Maarif”; "Müstemleke Iktisadiyat1, Mustakbil Millet Iktisadiyatı"; "Nafia Işleri”; and "Cemiyet, Gençlik, Kadın”.

38. See for instance Enver Ziya Karal, Türkiye Cumburiyeti Taribi (1918-1944) (Istanbul, 1945); idem, Osmanl Imparatorluğundan... Türkiye Cumburiyetine. Nasıldi? Nasıl Oldu? IO (Istanbul, I933).

39. See Türkiye Cumburiyeti Taribi (Ankara, 2005); Genelkurmay Başkanlığ1, Atatürkçülük (Istanbul, 200I).

40. Lewis, The Emergence of Modern Turkey; G.L. Lewis, Turkey (London, I955); Lord Kinross, Atatürk: A Biography of Mustafa Kemal, Father of Modern Turkey (New York, 1964).
} 
litany of legislation that reveals what the state elite wanted to happen and how they hoped to transform Turkish society, but it does not actually tell us what changes occurred or how Turks actually experienced the changes that accompanied the transition from empire to nation-state. It is precisely this, however, that the study of Ottoman and Turkish labour history can do very effectively, and the articles in the present Supplement are a contribution in that vein.

The articles in this Supplement span a period beginning in the nineteenth century and ending with the early I950s, when the initiation of multi-party politics made possible the active organization of workers. All but one concentrate on people actually living and working in the Ottoman Empire and Turkey. The exception is Iș1 Acehan's essay, which reminds us that an important aspect of the new global labour history is the recognition that it cannot - indeed must not - be contained within the artificial boundaries of the modern nation-state. Labour is, by definition, transnational: ${ }^{4 \mathrm{I}}$ today, the presence of millions of Turkish workers in Europe is a reality that cannot be ignored. By comparison, almost unknown is the fact that in the late nineteenth century Ottoman subjects - Turks, Kurds, and Armenians - emigrated to the eastern United States, where they made an important contribution to industrial production.

Iş1 Acehan's essay draws attention to this. In her case, "Ottoman labour history" concentrates not on the Middle East or lands under Ottoman control but across the Atlantic on immigrant workers in the state of Massachusetts. This movement originated with Armenians, but then grew to include Muslim subjects as well. Here the role of American missionaries in facilitating emigration was essential. Once in the United States, immigrant Ottoman workers integrated into the leather tanning industry in which there was growing demand for workers willing to undertake the most difficult and unpleasant tasks related to production. These workers exhibited close ties: either because they were members of broader families, or because they came from the same towns and villages in the Ottoman Empire. Interestingly, just as the coffee house played an important social function in Ottoman lands, so too in Massachusetts the coffee house provided an important place for sharing in the experience and surviving the dislocation of immigration. One consequence of this close interaction, however, was also the ready spread of disease.

Ottoman labourers in the United States represented various ethnic and religious backgrounds, and here there is a need for further research to be done on identity and labour in Massachusetts, although Acehan cautions against assuming that conflict was either inevitable or unique to the 
various groups. At the same time, we see that Turks were active in labour unions and strikes even if these were not particularly effective. Acehan demonstrates, however, that a commitment to labour activism superseded what otherwise might have been tensions between Greek and Turkish workers. That said, Ottoman entry into World War I appears to have accentuated the identity of Turkish workers as separate "enemy alien workers". In fact, many of these proved to be temporary migrants, for the I 920 s saw a decline in the number of Turkish workers as many returned home to the new Republic of Turkey.

Two articles specifically address aspects of industrial labour in the late Ottoman Empire itself. Gülhan Balsoy takes an innovative approach to exploring the relationship between gender and labour in the Cibali tobacco factory located on the Golden Horn in Istanbul. Employing a set of photographs taken in the nineteenth century, Balsoy not only makes women a visible element in the industrial labour force of the period but considers what these pictures reveal about the division of labour in various stages of industrial production. In the case of the Cibali factory, Balsoy concludes that there was indeed an ethnic division of labour. She interprets photographs to conclude that female workers in the Cibali factory represented non-Muslim minority communities rather than the majority Muslim population. Moreover, Balsoy concludes that there were indeed divisions of labour that reflected assumptions about gender roles in society as a whole: pictures suggest that men typically worked with machines while women did not; similarly, men appear to have been assigned more specialized work and women unskilled tasks. Yet Balsoy implicitly questions this very distinction by emphasizing that the actual tasks women carried out required care and precision, and thus cannot simply be dismissed as "unskilled".

Although photographs reveal much about the processes of industrial production, Balsoy cautions against taking such visual sources at face value, for often they present an ideal image of factory life, whereas archival documents suggest a far more difficult and hazardous existence for workers. Indeed the latter were witness to the contested nature of labour, as workers pushed to be granted improved working and living conditions. Photographs as well as textual documents reveal that women were active participants in protests and strikes, even if their efforts at activism were ultimately suppressed by the employer and/or the state.

In his study of the Imperial Fez Factory in late Ottoman Istanbul, Erdem Kabaday1 explicitly tackles the question of late Ottoman ethnic identities and the degree to which these played a part in industrial production. The question of an ethnic division of labour has long concerned historians of the Ottoman Empire, for both Orientalist and nationalisthistorical narratives of the "decline" of the Ottoman Empire emphasized a division between non-Muslim minorities allegedly more involved in 
business and industry, and "Turks" who were supposedly absent from these sectors of the economy. This division has been largely disproven, though scholars continue to explore it in further detail. ${ }^{42}$

The Imperial Fez Factory was one of the largest state-run industrial Ottoman enterprises - one that continued to operate until i986. It provided not only for the demands of the state but also for a domestic, free market. Kabadayı identifies very specific groups within the factory's workforce: unlike in the Cibali tobacco factory, women worked primarily from home, although again female workers were overwhelmingly nonMuslim. Kabadayı's focus, however, is on male employees whose identities can be discerned from a few registers he has found in the archives. Using these, Kabadayı demonstrates that workers migrated to Istanbul from parts of Anatolia and he argues that in fact regional identities were more important than ethnic or religious identities on the part of workers.

Determining ethnic or religious identification is not easy, and Kabaday1 discusses the various challenges to carrying out such a study and to reaching solid conclusions. He has ascertained that although the Orthodox Christian population represented a significant part of Istanbul's population, they were underrepresented within the factory. Kabadayı suggests that this was due primarily to political reasons following the establishment of Greek independence. He infers that this is because the Ottoman state did not wish minorities to work in military industrial enterprises. Nonetheless, Kabadayı argues that religion was not the sole determinant of group identity - rather, one must consider networks of migration, for workers who came from the same part of Anatolia tended to identify strongly with each other. In fact, wage differences and the division of labour can be accounted for along these lines as well as along ethnic and religious lines. At the very least, the reality is far more complicated than a simplistic ethnic division of labour.

This issue also surfaces in a third essay by Yavuz Köse in which he moves away from industry to investigate Istanbul's retail sector in the final years of the Ottoman Empire. Köse specifically examines Western department stores, and here too we find that non-Muslims constituted the vast majority of employees. Undertaking an analysis of the names of employees, he concludes that Jews, Greeks, Armenians, and Levantines/ Europeans each occupied reasonably distinct but visible positions within department stores. By contrast Muslim employees are largely invisible in the sources, although their position was no less distinct: as unskilled labourers they occupied the lowest ranks. Nevertheless, Köse suggests

42. For example, see Donald Quataert, The Ottoman Empire, I700-I922 (2nd edn, London, 2005); Peter Mentzel, “The 'Ethnic Division of Labor' on Ottoman Railroads: A Reevaluation”, Turcica, 37 (2005), pp. $22 \mathrm{I}-24 \mathrm{I}$. 
that there is evidence that employees overcame their ethnic identities to identify with workers in Ottoman industry: here he argues that precisely because employees lived in ethnically defined districts - rather than at their place of work, as was often the case in Europe - they were aware of the larger challenges facing Ottoman labour and even willing to strike in support of a common cause.

Köse, therefore, provides insight into an aspect of Ottoman labour that is largely obscured by the tendency among historians to concentrate on industrial workers. Again, the greatest challenge lies in a paucity of comprehensive sources, and he draws on a combination of private letters, memoirs, the Ottoman press, and the important statistical yearbook, Annuaire Oriental. The information is partial, and so Köse can only reconstruct tentatively the realities of employment in department stores: these include wages, duration of employment, place of residence, benefits and working conditions, and the possibilities of promotion. His conclusions provide useful points of comparison not only with other studies of late Ottoman labour, but also with those dealing with republican Turkish labour. Indeed Köse points to an important development in labour that occurred in the context of the political transition from empire to nationstate: this was the emergence of women as a visible and active part of the workforce as a result of World War I and then the Turkish War of Independence. As the subsequent essays demonstrate, women remained important to Turkish labour, although their contribution remains overshadowed by that of men and deserving of further study.

In this Supplement, three further essays address specific aspects of labour history in republican Turkey. Two essays approach the history of labour during the final years of the Republican Party's rule as the sole political party. These both address Turkish labour during World War II. Nurşen Gürboğa examines the famous Zonguldak coalfield. Specifically she concentrates on the relations between compulsory mineworkers and the state. In the context of the war, the government passed the National Defence Law on I 8 January 1940, and this permitted the conscription of men for industrial labour while also allowing for a relaxation of previous legislation that protected the rights of workers and guaranteed the conditions in which they worked. As a result of the National Defence Law, the mining workforce became bifurcated, comprising both free labour and compulsory workers, although the latter were very much in the majority.

In the case of Zonguldak, men living in the vicinity of mines found themselves forced to work long hours in awful conditions. Drawing on government reports as well as on the archives of the mining companies themselves, Gürboğa uncovers the extremely difficult conditions in which miners worked and lived, suffering a scarcity of food and the ravages of disease. At the same time, she demonstrates the realities that accompanied low wages and high inflation, as well as the impact of compulsory labour 
on surrounding villages and agricultural production from which men were removed.

Gürboğa's sources lead her to conclude that these workers were by no means passive, and that they did try to negotiate with the single-party state even if their options were limited; at the very least, deputies for the Republican People's Party clearly heard complaints from miners and their families. Ultimately, however, change came about not because of the actions of workers, but in context of emerging multi-party politics after I945: recognizing that it must cater to the constituents who would elect its deputies, the Republican People's Party began to alter its approach to labour in the Zonguldak coalfield and to phase out compulsory labour. It did so, however, under the pretext that this would increase productivity, not because it was responding to the concerns of workers expressed by labour organizations that had been allowed to form starting in I 947.

Can Nacar also addresses the history of workers engaged in Turkish industry during World War II. Specifically, he examines working conditions and the experiences of workers and how they challenged the social relations that the state imposed on them in the case of particular mines and factories owned and operated by the state-owned enterprises Sümerbank and Etibank. Nacar does use the work of other Turkish historians who have studied industrial workers, but he makes a point of criticizing their emphasis on ideal types rather than on real workers.

Drawing on the actual records of factories that Nacar has been fortunate to locate, he identifies just who workers were, where they came from, and how they came to work in industrial enterprises. Like Gürboğa, he is concerned to point out the very difficult conditions in which compulsory workers lived and functioned in the Zonguldak coalfield. Frequently these led to severe injury or death, while those who tried to flee found themselves pursued by the state and punished. Nonetheless, the high rate of turnover among employees suggests that not only did workers simply acquiesce in the demands of the state, but that the state itself was unable to impose its will on the people as effectively as the nationalist-historical narrative of Turkey has consistently implied.

Nacar's research reveals very clearly the challenges that decreasing real wages at a time of inflation as well as a shortage of goods posed for Turkish workers. They lacked the right to stage protests or strike, but Nacar demonstrates that this did not prevent workers from seeking higher wages either individually or as a group - he concludes that in some cases administrators actually responded favourably. This is perhaps less surprising in that state factories and mines did endeavour to address the practical needs of their workers: they provided food, although workers might reject it on account of its quality; housing facilities were available for some but not all, and conditions were far from ideal. Unhealthy conditions inevitably contributed to the spread of disease, and workers 
frequently suffered from epidemics. To respond to this, factories and mines established hospitals and provided various healthcare services to injured and sick workers.

In the final essay in this volume, Yiğit Akın allows workers to speak for themselves. The introduction of multi-party politics in 1945 and, soon after, the emergence of labour organizations - albeit limited in their activities - was accompanied by an unprecedented growth in the printed press. This occurred not only in metropolitan centres such as Istanbul, Ankara, and Izmir, but also in the provinces. And among those who turned to the printed word to express their interests and concerns were workers. Thus, Akın looks not at workers themselves or their experiences per se, but at the language they used in the press to describe their experiences as workers. More specifically, Akın analyses the development of Turkish working-class identity and politics in the I940s and I950s. While there were distinct changes in the government's approach to labour at this time, Akın identifies the emergence of a new discourse initiated by workers themselves - one that articulated demands concerning equality, justice, and human rights.

After 1945, newspapers contributed to a growing sense of common identity among workers, as they became aware of their place in society and role in the processes of production. Akin connects workers' concerns for rights with the rhetoric common to the Democrat Party seeking to claim votes after 1945 . Workers, conscious of their historically low social standing, struggled against this in their publications. At the same time, they emphasized their opposition to communism, even as the government used this potential threat as an excuse to suppress left-wing parties and trade unions.

In the pages of newspapers produced by and for workers, Akın found a strong rhetoric directed against employers, who were represented as harsh and cruel, rather than praise for the implementation of laws aimed at protecting workers and improving their conditions. There was, in short, in these years a strongly antagonistic relationship as workers drew attention to factories that violated labour law. At the same time, the state came in for criticism for failing to uphold the law and ensuring that necessary changes were in fact implemented - social justice was merely a mirage. Indeed, state officials and the management of industrial enterprises were impugned for working together to ensure that workers did not benefit from the full implementation of the law. In the pages of their newspapers, workers called for basic dignity, using cartoons, reportage, and poetry, contrasting highly profitable factories with the ill treatment and poverty suffered by employees. Low wages and long hours were a source of frustration, as was physical mistreatment at the hands of officials.

The essays in this Supplement by no means offer a comprehensive picture of labour in the late Ottoman Empire or the Republic of Turkey. Unfortunately, none of them deals with labour during the period of Mustafa 
Kemal's presidency between 1923 and 1938 - which is not to say that this period can be ignored on account of the power over society wielded by the single party state. Nor do the essays address all of the theoretical and methodological issues that necessarily arise in the study of labour.

The authors represent some of those engaged in this important enterprise, whether they are studying more recent developments or those of earlier periods. ${ }^{43}$ In Turkey itself, scholars are publishing a variety of monographs in Turkish, as well as articles in journals such as Toplum ve Bilim and Tarib ve Toplum. ${ }^{44}$ Moreover, Turkish universities - particularly the Atatürk Institute at Bosphorus University in Istanbul - are actively engaged in promoting critical, source-based analysis of labour history by a seemingly ever-growing cadre of young scholars. Many of the contributors to this volume began their careers in such institutions.

Clearly, there is more work to be done, and many more sources to be uncovered. More importantly there is a need for scholars of Ottoman and Turkish labour history to actively engage the larger field of global labour history on a consistent basis. Here, many questions continue to be asked, and historians of the Middle East have an important contribution to make. This Supplement is a step in that direction, and there can be no doubt that as the new, younger generation of labour historians studying the Ottoman Empire and the Republic of Turkey continue their work, the Middle East will increasingly become a part of the discourse concerning Global Labour History. That in turn will constitute an important development in the social history of both the Ottoman Empire and the Republic of Turkey, and in efforts to compare and contrast the experiences of people living in and between the two states in the nineteenth and twentieth centuries.

43. A valuable study of more recent aspects of labour in Turkey is Erol Kahveci, Nadir Sugur, and Theo Nichols (eds), Work and Occupation in Modern Turkey (New York, 1996).

44. See for example Engin Yıldırım, "İşçi sınıfından bir kesit: Gebze metal işçileri", Toplum ve Bilim, 68 (1995), pp. I 58-ı63; Ahmet Makal, “Türkiye'nin sanayileşme sürecinde işgücü sorunu, sosyal politika ve İktisadi Devlet Teşekkülleri: I930'lu ve I940'l yıllar”, Toplum ve Bilim, 92 (2002), pp. 34-70; Chris Hann and Ildiko Bellér Hann, "Mazlum olan kim? Rize'deki çay üreticileri örneği”, Toplum ve Bilim, 88 (200I), pp. 55-68. 